\title{
PENGARUH PENAMBAHAN TEPUNG RUMPUT LAUT Eucheuma cottonii TERHADAP PEMBUATAN MASKER WAJAH
}

\author{
Safriyanto S Maruka ${ }^{1)}$ dan Nurfadilah ${ }^{1)}$ \\ ${ }^{1}$ Program Studi Teknologi Pengolahan Hasil Laut, Politeknik Palu \\ Email : edimaruka@yahoo.co.id; nurfadilah.mh@gmail.com
}

\begin{abstract}
Face masks are cosmetics that used to brighten facial skin and protect against free radical damage while maintaining skin's youthfulness. Eucheuma cottonii seaweed is a seaweed that has useful content for the skin, including high antioxidant content, and could use as an essential ingredient in facial masks. The aim of this study to determine the effect of different ratios of seaweed addition to $\mathrm{pH}$, time of drying, and organoleptic preparation, while the benefits of this research were as information material about the use of Eucheuma cottonii seaweed as a natural mask and IPTEK contribution to Central Sulawesi. The research carried out in August 2017 at the Basic Laboratory and the Laboratory of Applied Marine Products Processing Technology, Palu Polytechnic. This research used Randomized Group Desig for Organoleptic and Completely Randomized Design for $\mathrm{pH}$ and drying time, with 5 treatments each repeated 3 times, so there are 15 experimental units. The $\mathrm{pH}$ value of Eucheuma cottonii seaweed facial masks on each treatment showed that there was no significant difference in the pH value of 7.2 for each treatment. In contrast, for the dried treatment was the best, A5 treatment with a drying time of 20.6 minutes. The quality of Eucheuma cottonii seaweed based on each treatment that was by the applied standards, so the best concentration was on A5 treatment. The $p H$ value, drying time, and organoleptic preparations in this study generally meet the quality standards of masks set by the Indonesian National Standards and supported by existing research results.
\end{abstract}

Keywords : Seaweed Flour, Mask, Physical Properties

\section{PENDAHULUAN}

Indonesia memiliki laut yang pantainya kaya akan berbagai sumber hayati dan lingkungannya potensial. Keadaan tersebut merupakan salah satu faktor yang dapat menunjang keberhasilan disektor perikanan (Ega $d k k$, 2016).Salah satu jenis rumput laut yang dibudidayakan oleh masyarakat adalah Eucheuma cottonii (Kappaphycus alvarezii). Jenis ini banyak dibudidayakan karena teknologi produksinya relatif murah dan mudah serta penanganan pasca panen mudah dan sederhana (Wijayanto, $d k k$ 2011).

Rumput laut jenis Eucheuma cottonii termasuk dalam golongan ganggang merah (Rhodophyceae) penghasil karaginan. Karaginan merupakan hidrokoloid yang penting karena memiliki aplikasi yang sangat luas dalam industri pangan dan non pangan. Dalam dunia industri dan perdagangan karaginan mempunyai manfaat yang sama dengan agar-agar dan alginat. Karaginan dapat digunakan sebagai bahan baku untuk industri farmasi, kosmetik dan lain-lain. Kegunaan karaginan, antara lain sebagai pengatur kestabilan produk, bahan pengental, pembentuk gel dan pengemulsi (Anggadiredja. 2008)

Rumput laut memiliki kandungan yang baik untuk kulit, diantaranya adalah kandungan antioksidan yang berperan dalam penyembuhan dan peremajaan kulit. Vitam A dan Vitamin C nya bekerja dalam memelihara kolagen. Sedangkan kandungan protein dari rumput laut penting untuk membentuk jaringan baru pada kulit sehingga mencegah penuaan dini. Rumput laut sebenarnya kaya akan kandungan 
Vitamin B kompleks, C, magnesium, dan berbagai miniral lainnya yang membantu metabolisme sel kulit (Hika, 2013).

Masker wajah adalah pasta krim (gel) yang diterapkan pada wajah setelah dibersihkan. Masker sering mengandung mineral, vitamin dan protein. Ada berbagai jenis masker untuk tujuan yang berbeda : deep cleansing dngan menembus poro-pori, menembuhkan bekas jerawat atau hiperpigmentasi, pencerah untuk mencerahkan warna kulit secara bertahap. Masker wajah dapat dihilangkan dengan membilas wajah dengan air atau menyeka wajah dengan kain lembab hingga bersih (Aceng R.F \& Rina Nurmalina 2012).

Masker wajah umumnya terbuat dari tepung beras sebagai bahan utamanya, namun pada penelitian ini produk masker yang akan dibuat menggunakan rumput laut dan tapioka. Tapioka sebagai dipergunakan sebagai bahan membuat makanan, dan dapat bermanfaat pula dalam merawat kesehatan dan kecantikan kulit. Tapioka bersifat dingin sehingga dapat mendinginkan kulit secara cepat. Fungsi dari tapioka dalam pembuatan masker wajah yaitu sebagai perekat, sehingga apabila masker ditempelkan pada kulit dapat melekat dan menimbulkan rasa kencang. (Kartodimedjo, Sri. 2013).

Berdasarkan hal tersebut maka perlu adanya produk masker yang menggunakan bahan yang aman untuk kulit, Salah satunya dengan memproduksi masker rumput laut. Penulis melakukan penelitian tentang formulasi rumput lautterhadap $\mathrm{pH}$, waktu sediaan mengering dan Uji Organoleptik.

\section{Tujuan dan Manfaat}

Tujuan dalam Penelitian ini adalah untuk mengetahui pengaruh penambahan tepung rumput lautyang berbeda terhadap $\mathrm{pH}$, waktu sediaan mengering dan Mutu organoleptik masker rumput laut.

Sedangkan manfaat dari penelitian ini adalah sebagai bahan informasi tentang pemanfaatan rumput laut Eucheuma cottonii sebagai masker alami dan sumbangsi IPTEK bagi Daerah Sulawesi Tengah.

\section{METODOLOGI}

Waktu dan Tempat

Penelitian ini akan dilaksanakan pada bulan Agustus 2019 di Laboratorium Dasar dan Laboratorium Terapan Teknologi Pengolahan Hasil Laut, Politeknik Palu.

\section{Alat dan Bahan}

Alat yang digunakan diantaranya yaitu pisau, blender, kompor, panci masak, talenan, tampi pengering, sendok, timbangan analitik, baskom besar, baskom kecil, ayakan 60 mesh. Sedangkan bahanbahan yang digunakan pada praktikum ini, yaitu rumput laut Eucheuma cottonii, tapioka, bengkoang, dan kulit semangka.

\section{Rancangan percobaan}

Penelitian ini dirancang menggunakan metode RAK (Rancangan Acak Kelompok) untuk uji organoleptik dan RAL (Rancangan Acak Lengkap) untuk pengujian $\mathrm{pH}$ dan waktu sediaan mengering, dengan 5 perlakuan maisngmasing di ulang sebanyak 3 kali sehingga terdapat 15 satuan percobaan. Untuk mengetahui pengaruh perlakuan yang diujikan maka dilakukan analisis sidik ragam dan jika perlakuan berpengaruh nyata dilanjutkan dengan uji BNT (Hanifiah, 2005). Parameter yang diamati meliputi : $\mathrm{pH}$ dan Waktu Sediaan Mengering, dan untuk Organoleptik Aroma, Warna dan Tekstur. Adapun Formula masker wajah berbasis rumput laut Eucheuma cottonii di lihat pada Tabel 1 :

Tabel 1. Formula Masker Wajah Berbasis Rumput Laut

\begin{tabular}{|c|c|c|c|c|c|}
\hline Batun & & & Pelakusa & & \\
\hline & $A_{i}$ & $A_{5}$ & $A_{i}$ & $A_{i}$ & $A_{t}$ \\
\hline Ramput Lut & $0 \pi$ & 105 & 58 & $\mathrm{~B}_{\mathrm{I}}$ & $18 \pi$ \\
\hline Bendaing Bequad & $20 \mathrm{~s}$ & 205 & $20 t$ & $20 \pi$ & $20 \mathrm{~s}$ \\
\hline Tepiaba sequed & $3 n$ & 38 & 38 & $3 n$ & 3 \\
\hline Kulit Senando & 10 al & $10 \mathrm{ne}$ & $10 \mathrm{~m}$ & $10 \mathrm{~m}$ & $10 \mathrm{~m}$ \\
\hline
\end{tabular}

\section{Prosedur Penelitian}

\section{Pembuatan Rumput Laut Bentuk Chip}

Pembuatan chip rumput laut adalahrumput laut Eucheuma cottonikering ditimbang sebanyak $1 \mathrm{~kg}$ diletakkan ke 
dalam baskom besar kemudian cuci sampai bersih lalu dan rendam didalam air yang mengandung kapur tohor $0,5 \%$ selama \pm 24 jam. Rumput laut Eucheuma cottoni yang telah direndam ditiriskan dan dicuci sampai bersih, kemudian rendam kembali ke dalam larutan Kalium Hidroksida (KOH) $0,15 \%$ selama 1 x 24 jam. Setelah direndam cuci kembali sampai bersih lalu tiriskan dan potong-potong dengan ukuran $2-3 \mathrm{~cm}$, selanjutnya keringkan dibawah sinar matahari atau pada mesin pengering sampai benar-benar kering. Setelah kering simpan chip rumput laut Eucheuma cottonii (Mappiratu, 2015).

\section{Pembuatan Masker Wajah Berbasis Rumput Laut Eucheuma cottoni}

Rumput laut dimasak dengan air sebanyak $400 \mathrm{ml}$, kemudian di hancurkan dengan blender. Hancuran rumput laut ditambahkan bengkoang bahan sesuai perlakuan, tapioka sesuai perlakuan dan kulit semangka sesuai perlakuan. Campuran di adon hingga membentuk adonan, selanjutnya di keringkan dengan sinar matahari hingga kering. Masker kering dihancurkan dengan blender, di ayak dengan ayakan 60 mesh untuk mendapatkan masker bentuk bubuk (Mappiratu, 2015).

\section{Analisis Fisik Masker Rumput Laut Eucheuma cottonii Pengujian pH}

Uji $\mathrm{pH}$ dilakukan dengan menggunakan alat $\mathrm{pH}$ meter. Nilai $\mathrm{pH}$ yang muncul dilayar dicatat. Uji ini untuk mengukur derajat keasaman sediaan dengan cara $\mathrm{pH}$ meter di netralkan terlebih dahulu menggunakan larutan buffer. Pengukuran $\mathrm{pH}$ yang terdapat pada masker dengan menimbang masker rumput laut 5 gr dan di larutkan $20 \mathrm{ml}$ aquadest, dan pengukuran $\mathrm{pH}$ dengan menggunakan $\mathrm{pH}$-meter digital, syarat $\mathrm{pH}$ standar untuk masker adalah 4-8 (Rowe, Sheskey and owen, 2006).

\section{Pengujian Waktu Sediaan Mengering}

Pengujian waktu sediaan mengering dilakukan dengan cara mengoleskan masker rumput laut \pm 1 g berbagai konsentrasi ke punggung tangan dan diamati waktu yang diperlukan sediaan untuk mengering, dari saat mulai dioleskannya masker rumput laut hingga benar-benar terbentuk lapisan yang kering. Waktu tersebut dibandingkan dengan waktu kering masker produk inovator yang beredar dipasaran yaitu sekitar 10-30 menit pengujian dilakukan pada awal pembuatan dan terakhir waktu penyimpanan.pengujian ini perlu dilakukan sediaan masker, karena untuk melihat daya rekat yang terjadi (Vieira, 2009).

\section{Uji Organoleptik}

Pengujian organoleptik dilakukan untuk mengetahui tingkat kesukaan atau kelayakan suatu prodak agar dapat diterima oleh konsumen. Pengujian menggunakan skala hedonik dan numerik. Adapun parameter yang diuji adalah aroma, warna, tekstur, daya lekat dan kesukaan dengan panelis tidak terlatih yang berjumlah 20 orang.(Soekarno 1994 dalam Novitasari, 2009), Skor sheet penilaian yang digunakan untuk aroma, warna dan tekstur dapat dilihat pada Tabel 2, 3 dan 4 .

Tabel 2. Skor Sheet Penilaian Organoleptik Kesukaan Aroma

\begin{tabular}{cc}
\hline Skala Hedonik & Skala Numerik \\
\hline sangat suka & 5 \\
Suka & 4 \\
Netral & 3 \\
Tidak suka & 2 \\
Sangat tidak suka & 1 \\
\hline
\end{tabular}

Sumber : Kartikasari,(2015).

Tabel 3. Skor Sheet Penilaian Organoleptik Warna

\begin{tabular}{cc}
\hline Skala Hedonik & Skala Numerik \\
\hline sangat Putih & 5 \\
Putih & 4 \\
Netral & 3 \\
Tidak Putih & 2 \\
Sangat Tidak Putih & 1 \\
\hline
\end{tabular}

Sumber: Kartikasari, (2015). 
Tabel 4. Skor Sheet Penilaian Organoleptik Tekstur

\begin{tabular}{cc}
\hline Skala Hedonik & Skala Numerik \\
\hline Sangat Halus & 5 \\
Halus & 4 \\
Netral & 3 \\
Tidak Halus & 2 \\
Sangat Tidak Halus & 1 \\
\hline
\end{tabular}

Sumber : Kartikasari, (2015)

\section{Analisis Data}

Analisis Data hasil pengamatan ialah dengan analisis ragam dengan menggunakan rancangan acak lengkap (RAL) untuk pengujian $\mathrm{pH}$ dan kesediaan mengering. Menurut petunjuk (Sastrosupadi, 2000) model matimatis adalah sebagai berikut :

$$
\text { Yij }=\mu+T_{i}+E_{i j}
$$

Keterangan :

Yij = Nilai pengamatan dari perlakuan ke-i dan ulangan ke-j

$\mu \quad=$ nilai tengah

$\mathrm{Ti}=$ pengaruh perlakuan ke- $\mathrm{i}$

Eij = pengaruh galat percobaan dari perlakuan ke-i dan ulangan ke-j

Jika hasil analisis ada perbedaan antara perlakuan maka dilakukan pengujian lebih lanjut yaitu dengan menggunakan uji beda nyata terkecil (BNT) (Sastrosupadi, 2000).

Data hasil pengamatan ialah dengan analisis menggunakan rancangan acak kelompok (RAK). Untuk pengujian Organoleptik. Menurut petunjuk ( Hanafiah, 2005), Model matematis adalah sebagai berikut :

$$
Y i j=u+T i+B j+E i j
$$

Keterangan :

Yij = Nilai pengamatan perlakuan

$\alpha=$ Pengaruh perlakuan

$\mathrm{Bj} \quad=$ Jumlah ulangan

Eij = Galat percobaan

I = Perlakuan

$\mathrm{J}=$ Ulangan

$\mu \quad=$ Rata-rata umum pengamatan
3. HASIL DAN PEMBAHASAN Analisis pH Masker Wajah Berbasis Rumput Laut Eucheuma cottonii

Pengujian $\mathrm{pH}$ dimaksudkan untuk mengetahui nilai $\mathrm{pH}$ pada masker wajah berbasis rumput laut Eucheuma cottonii. Nilai pH sangat penting untuk melihat tingkat keasaman dan menjamin masker yang dihasilkan tidak menimbulkan iritasi pada wajah. Selain itu, pengukuran $\mathrm{pH}$ bertujuan untuk mengamati perubahan $\mathrm{pH}$ yang mungkin terjadi pada setiap konsentrasi rumput laut Eucheuma cottonii.

Hasil analisis sidik ragam menunjukan tidak berpengaruh nyata, nilai rataan $\mathrm{pH}$ masker wajah berbasis rumput laut Eucheuma cottonii disajikan pada Gambar 1.

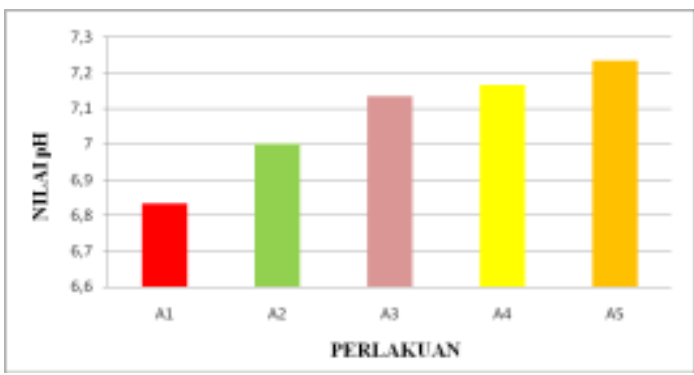

Gambar 1. Histogram Nilai pH pada masker dengan level penambahan rumput laut Eucheuma cottonii yang berbeda.

Berdasarkan Gambar 1, terlihat kenaikan dan penurunan nilai $\mathrm{pH}$.Nilai $\mathrm{pH}$ perlakuan A5(7,23) dan A4(7,16) memiliki nilai $\mathrm{pH}$ tertinggi,selanjutnya diikuti dengan perlakuan $\mathrm{A} 3(7,13)$ dan nilai $\mathrm{pH}$ yang terendah yaitu A2 (7) dan A1 (6,83). Hal ini dipengaruhi karena pada proses pembuatan masker wajah berbasis rumput laut Eucheuma cottonii ditambahkan bengkoang, tapioka dan kulit semangka yang berbeda, semakin banyak konsentrasi rumput laut maka $\mathrm{pH}$ semakin meningkat. Hal ini diduga karena $\mathrm{pH}$ karaginan yang terkandung didalam rumput laut yang tinggi menyebabkan peningkatan nilai $\mathrm{pH}$ pada masker wajah rumput laut. Hal ini sesuai dengan Yasita dan Rachmawati (2009), proses pengolahan karaginan yang 
terkandung didalam rumput laut di ekstrasikan menggunakan $\mathrm{NaOH}$ atau $\mathrm{KOH}$ akan menyebabkan $\mathrm{pH}$ karaginan menjadi tinggi yang kemudian akan mempengaruhi produk olahannya.

\section{Analisis Waktu Sediaan Mengering Berbasis Rumput Laut Eucheuma cottonii}

Pengujian waktu sediaan mengering dilakukan untuk mengetahui waktu kering sampai benar-benar mengering yang dibandingkan dengan produk inovator atau produk yang ada dipasaran. Pengujian ini perlu dilakukan terhadap sediaan masker, karena untuk melihat daya rekat yang terjadi. Hasil pengujian waktu sediaan mengering dapat dilihat pada Gambar 2. Hasil analisis sidik ragam sediaan kering, menunjukkan bahwa penambahan rumput laut yang berbeda tidak berpengaruh nyata atau hampir sama.

Nilai rataan waktu sediaan mengering masker wajah berbasis rumput laut Eucheuma cottonii disajikan pada Gambar 2.

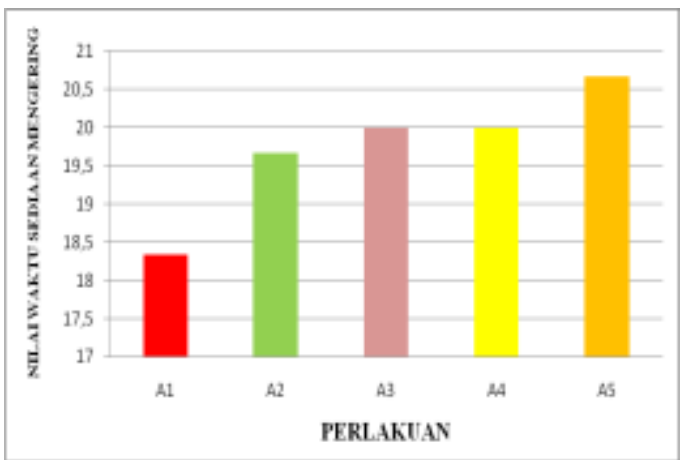

Gambar 2. Histogram Nilai Waktu Sediaan Mengering pada masker dengan level penambahan rumput laut Eucheuma cottonii yang berbeda.

Hasil uji waktu sediaan mengering pada Gambar di atas menunjukkan bahwa hasil yang diperoleh bervariasi dimana A3 dan A4 memiliki hasil yang sama, tetapi untuk perlakuan A5 memiliki nilai waktu sediaan mengering dengan waktu yang lama (20,6) menit, hal ini karena penambahan rumput laut yang tinggi, dimana rumput laut memiliki sifat kekuatan gel atau kekentalan yang tinggi. Syamsuar (2007), menyatakan sifat kekuatan gel inilah yang menyebabkan rumput laut sangat luas penggunaanya, baik dalam bidang pangan maupun bidang farmasi. Pada perlakuan A5 waktu kesediaan kering cepat $(18,3)$, karena tidak memakai rumput laut atau hanya pengontrol.

Mutu Organoleptik Masker Wajah Berbasis Rumput Laut Eucheuma Cottonii

Aroma

Parameter aroma yang diujikan ialah aroma yang akan mempengaruhi kesukaan panelis terhadap masker rumput laut. Data hasil pengujian organoleptik terhadap nilai aroma masker wajah berbasis rumput laut Eucheuma cottoniidan sidik ragam. Hasil analisis sidik ragam menunjukan tidak berpengaruh nyata. Nilairataan aroma masker wajah berbasis rumput laut Eucheuma cottonii disajikan pada Gambar 3.

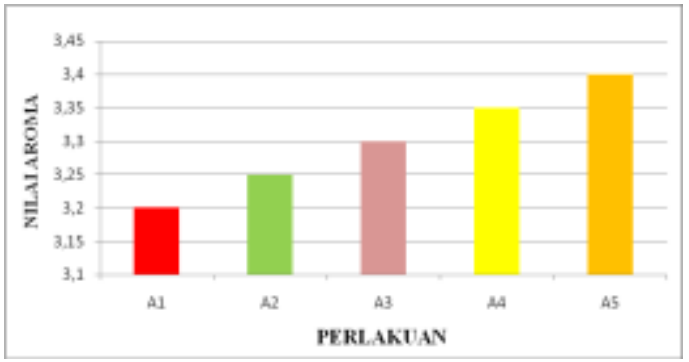

Gambar 3. Histogram Nilai Aroma pada masker dengan level penambahan rumput laut Eucheuma cottonii yang berbeda.

Berdasarkan Gambar 3 dapat terlihat kenaikan dan penurunan nilai aroma masker.Nilai aroma perlakuan A5 dan A4 memiliki nilai aroma khas rumput laut tertinggi $(3,4)$, diikuti perlakuan A4 $(3,35)$, selanjutnya diikuti dengan perlakuan A3 $(3,3)$ dan A2 $(3,25)$ nilai masker yang terendah yaitu A1 $(3,2)$. Semakin banyak konsentrasi rumput laut maka aroma rumput laut semakin meningkat. Hal ini diduga karena rumput laut memiliki aroma yang dapat menimbulkan aroma asing pada 
masker apabila konsentrasinya berlebihan. Hal ini sesuai dengan pernyataan Eveline $d k k(2009)$ yang menyatakan bahwa aroma asing dari masker berasal dari rumput laut yang memiliki karakteristik berbau amis.

\section{Warna}

Data hasil pengujian organoleptik terhadap nilai warna masker wajah berbasis rumput laut Eucheuma cottoniidan. Hasil analisis sidik ragam menunjukan tidak berpengaruh nyata. Nilai rataan warna masker wajah berbasis rumput laut Eucheuma cottonii disajikan pada Gambar 4.

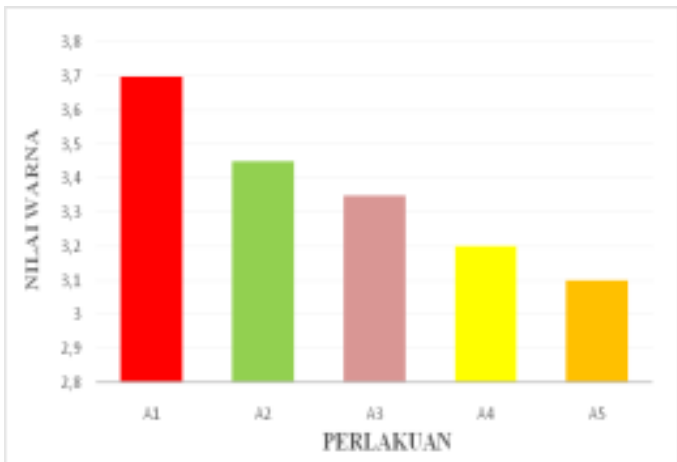

Gambar 4. Histogram Nilai Warna pada masker dengan level penambahan rumput laut Eucheuma cottonii yang berbeda.

Berdasarkan Gambar 4 dapat terlihat kenaikan dan penurunan nilai penampakan warna masker.Penilaian tertinggi pada perlakuan A1 $(3,7)$ dan A2 $(3,45)$, di ikuti A3 $(3,35)$ dan A4 $(3,2)$. Kenampakan merupakan salah satu parameter organoleptik yang penting karena merupakan faktor yang pertama dilihat oleh konsumen saat melihat prodak dan umumnya konsumen cenderung memilih masker yang memiliki kenampakan yang menarik (Chaplin, 2005). Sedangkan nilai terendah pada perlakuanA4 $(3,2)$ dan A5 $(3,1)$. sehingga dapatmempengaruhi produk akhir masker. Menurut setyaningsi $d k k$ (2010), penilaian kualitas sensori dapat dilakukan dengan melihat bentuk, ukuran, kejernihan, kekeruhan, warna serta sifatsifat permukaan seperti kasar-halus, suram, mengkilap, homogen-heterogen dan datarbergelombang. Sifat warna yang mudah dikenali dapat mempengaruhi respon dan presepsi panelis.

\section{Tekstur}

Data hasil pengujian organoleptik terhadap nilai warna masker wajah berbasis rumput laut Eucheuma cottoniidan. Hasil analisis sidik ragam) menunjukan berpengaruh sangat nyata, nilai rataan warna masker wajah berbasis rumput laut Eucheuma cottonii disajikan pada Gambar 5.

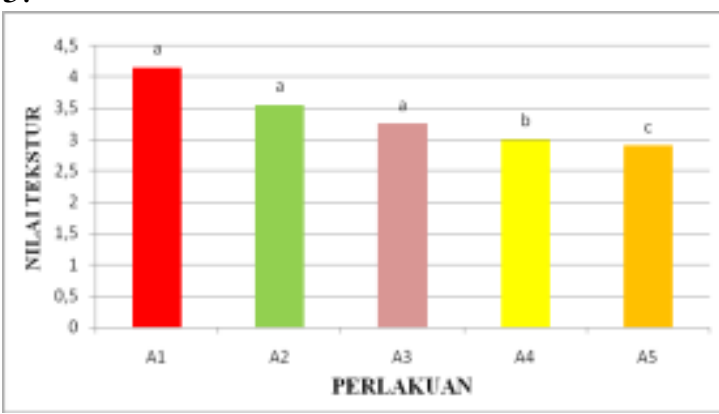

Gambar 5. Histogram Nilai Tekstur pada masker dengan level penambahan rumput laut Eucheuma cottonii yang berbeda.

Dapat dilihat pada Gambar 5 bahwa rata-rata skor organoleptik terhadap tekstur masker yang diperoleh dari hasil penelitian antara 2,9 sampai dengan 4,15 skor tersebut menunjukkan bahwa kesukaan panelian tekstur masker rumput laut diantara ada tidak menyukai sampai sangat suka skor organoleptik yang terendah A5 pada penggunaan rumput laut 18 gr sedangkan tekstur tertinggi diperoleh pada perlakuan A1 yaitu tanpa penggunaan rumput laut artinya panelis atau konsumen lebih menyukai tanpa penggunaan rumput laut dari pada peningkatan penggunaan

rumput laut. Tekstur masker yang lebih padat, lembut dan halus diakibatkan banyaknya kandungan pati dari tepung tapioka, kulit semangka dan bengkoang lebih disukai konsumen dari pada peningkatan penggunaan rumput laut. Sagianto (2002) bahwa penambahan bahan padatan menyebabkan fraksin non air meningkat dan jarak antara partikel 
menurun sehingga menyebabkan prodak lebih berisi dan nilai teksturnya menjadi lebih berisi. Sesuai dengan pengujian secara mekanik.

\section{KESIMPULAN}

Berdasarkan hasil penelitian menunjukkan bahwa nilai $\mathrm{pH}$ masker wajah berbasis rumput laut Eucheuma cottonii pada setiap perlakuan menunjukkan bahwa tidak berbeda nyata nilai $\mathrm{pH}$ setiap perlakuan, sementara untuk perlakuan waktu sediaan mengering perlakuan yang terbaik yaitu perlakuan A4 dengan nilai waktu sediaan mengering 20,6 menit. Kualitas berbasis rumput laut Eucheuma cottonii berdasarkan setiap perlakuan yang sesuai dengan standar yang diterapkan, maka konsentrasi yang baik ada pada perlakuan A4. Nilai pH, waktu sediaan mengering dan organoleptik pada penelitian ini secara umum memenuhi standar mutu masker yang ditetapkan oleh Standar Nasional Indonesia serta ditunjang dari hasil penelitian yang telah ada.

\section{REFERENSI}

Aceng R. F. \& Nurmalina, Rin. 2012. Merawat Kulit \& Wajah. Jakarta : Elex Media Komputindo.

.Chaplin, 2005. Gelatin. www//Isbuc.ac.uk. Diakses pada tanggal 22 Juni 2019.

Ega, La,Cynthia Gracia Cristina Lopulalan dan Firat Meiyasa.2016.Kajian Mutu Karaginan Rumput Laut Eucheuma cottonii Berdasarkan Sifat Fisiko-Kimia pada Tingkat Konsentrasi Kalium Hidroksida $(\mathrm{KOH}) \quad$ yang Berbeda.Jurnal Aplikasi Teknologi Pangan 5 (2).

Eviline., Santoso, J., dan Widjay. I. 2009. Pengaruh Konsentrasi dan Rasio Gelatin dari Kulit Ikan Patin dan Kappa Karagenan dari eucheuma cottonii Pada Pembuatan Jeli. Jurnal Ilmu dan Teknologi Pangan, 7 (2) : 55-75.

Hika, 2013. Proses Pembuatan Sabun Rumput Laut (Kappaphycus Alvarezi). Balai Pustaka Jakarta.
Kartikasari, 2015. Pengaruh Proporsi Pati Bengkuang dan Tepung Kentang Terhadap Hasil Jadi Masker Untuk Perawatan Kulit Wajah Flek Hitam Bekas Jerawat. Universitas Negri Surabaya.

Kartodimedjo, Sri. 2013. Cantik Dengan Herbal Rahasia Putri Keraton. Yogyakarta : Citra Media Pustaka.

Mappiratu. 2015. Modul Praktikum Teknologi Pengolahan Rumput Laut II. Palu : Teknologi Pengolahan hasil Laut, Politeknik Palu.

Rowe, G.R., P.J.Sheskey, S.C.Owen, 2006, handbook of Pharmaceutical Excipients 5th Edition, Pharmaceucital Press: London.

Sagianto, H. 2002. Pembuatan Sosis Jamur Tiram Putih (pleurotus florida) Kajian Penambahan Susu Skim dan Tepung Maizena Terhadap Sifat Fisik, Kimia dan Organoleptik. Skripsi. Fakultas Teknologi Pertanian. Universitas Brawijay. Malang.

Sastrosupadi, adji. 2000. Rancangan Percobaan Praktis Bidang Pertanian. Yogyakarta : Kanisius.

Setyaningsih, D., Anton Apriyantono, Maya Puspitasari. 2010. Analisis Sensori untuk Industri Pangan dan Agro. IPB Press. Bogor.

Soekarno, (1994) dalam Novitasari, (2009). Mutu Kimia dan Organoleptik Permen Jelly Rumput Laut Gelatin Sapi. Program Pasca arjana Universitas Tadulako Palu.

Syamsuar. 2002. Karakteristik Karaginan Rumput Laut Eucheuma Cototonii Pada Berbagai Umur Panen, Konsentrasi $\mathrm{KOH}$ dan Lama Ekstraksi. [tesis]. Bogor. Sekolah Pascasarjana IPB.

Viera, R.P. 2009. Physical and Physicochemical Stability Evaluation of Cosmetic Formulation Containing Soybean Extract Fermented by Bifidobacterium Animalis. Brazilian Journal of 
KAUDERNI : Journal of Fisheries, Marine and Aquatic Science https://jurnal.stplpalu.ac.id/index.php/kauderni/index

Volume 2, Nomor 1, (2020)

ISSN 2541-0571

Pharmaceutical Sciences, 45 (3):515-525.

Wijayanto,Tri, Muhammad Hendri, Riris Aryawati. 2011. Studi

Pertumbuhan Rumput Laut

Eucheuma cottoni dengan

Berbagai Metode Penanaman

yang berbeda di Perairan

Kalianda, Lampung Selatan.

Program Studi Ilmu Kelautan
FMIPA Universitas Sriwijaya, Indralaya Indonesia.

Yasita D, racmawati ID. (200)., Optimasi proses ekstrasi pasa pembuatn karaginan dari riumput laut eucheuma cottonii untuk mencapai foodgrade. Skrip. Jurusan Teknik Kimia Fakultas Teknik Universitas Dipenogoro, semarang. 